University of Wollongong

Research Online

Faculty of Law, Humanities and the Arts Papers (Archive)

Faculty of Arts, Social Sciences \& Humanities

$1-1-2013$

Comparative legal cultural analyses of international economic law: a new methodological approach

Colin B. Picker

University of New South Wales, cpicker@uow.edu.au

Follow this and additional works at: https://ro.uow.edu.au/lhapapers

Part of the Arts and Humanities Commons, and the Law Commons

Research Online is the open access institutional repository for the University of Wollongong. For further information contact the UOW Library: research-pubs@uow.edu.au 


\title{
Comparative legal cultural analyses of international economic law: a new methodological approach
}

\author{
Abstract \\ The effective development and operation of the law faces many obstacles. Among the more intractable \\ yet hidden barriers to the law are legal cultural disconnects and discontinuities. These occur when \\ opposing legal cultural characteristics from different legal cultures are forced to interact as part of the \\ implementation of the law across two different legal cultures. This conflictual interaction can impede or \\ block the success of that law. While present in domestic legal systems, these conflicts are more likely, \\ and may be deeper, between the many different legal cultures involved in the international legal order. \\ Identification of such legal cultural disconnects and discontinuities is the first step towards developing \\ strategies to ameliorate potential conflicts between opposing legal cultural characteristics. This \\ identification requires the examination of the relevant legal systems with legal culture in mind-a legal \\ cultural analysis. However, this methodology is rarely employed. To the extent that we do see legal \\ cultural analyses, they are applied almost exclusively in the domestic arena. When it is applied across \\ legal systems, it becomes a part of comparative law methodology. This merger of comparative law and \\ legal cultural approaches is unusual, indeed almost unheard of in the international legal arena. This article \\ explores this methodology and argues that it is possible and valuable.

\section{Disciplines} \\ Arts and Humanities | Law

\section{Publication Details} \\ C. B. Picker, 'Comparative legal cultural analyses of international economic law: a new methodological \\ approach' (2013) 1 (1) The Chinese Journal of Comparative Law 21-48.
}




\title{
Comparative Legal Cultural Analyses of InTERnational ECONOMic LAW: A NeW METHOdOLOGICAL APPROACH
}

\author{
Colin B. Picker*
}

\begin{abstract}
The effective development and operation of the law faces many obstacles. Among the more intractable yet hidden barriers to the law are legal cultural disconnects and discontinuities. These occur when opposing legal cultural characteristics from different legal cultures are forced to interact as part of the implementation of the law across two different legal cultures. That conflictual interaction can impede or block the success of that law. While present in domestic legal systems, those conflicts are more likely and the conflicts may be deeper between the many different legal cultures involved in the international legal order. Identification of such legal cultural disconnects and discontinuities is the first step towards developing strategies to ameliorate potential conflicts between opposing legal cultural characteristics. That identification requires examination of the relevant legal systems with legal culture in mind-a legal cultural analysis. But, that methodology is rarely employed. To the extent we do see legal cultural analyses, they are applied almost exclusively in the domestic arena. When it is applied across legal systems it becomes a part of comparative law methodology. This merger of comparative law and legal cultural approaches is unusual, indeed almost unheard of in the international legal arena. This article explores that methodology, to argue that it is possible and valuable.
\end{abstract}

\footnotetext{
* Associate Professor, University of New South Wales, Sydney, Australia. A.B. (Bowdoin College), J.D. (Yale Law School) (c.picker@unsw.edu.au). I would like to thank Ross Buckley, Leon Trakman, and Lisa Toohey for their help with this work.
} 


\section{INTRODUCTION}

International economic law ("IEL") has come of age: it is almost seventy years since the birth of the International Monetary Fund ("IMF") and the World Bank; the World Trade Organization ("WTO") has now existed for almost two decades; and in recent years there have been thousands of bilateral investment treaties and hundreds of preferential trade agreements launched. Furthermore, there are now countless books, articles, reports, institutions, and specialized degrees in the field to attest to IEL's maturity. Yet, like much of international law, IEL has traditionally been analysed through conventional research methodologies. Given the level of maturity of the field it is now time that it is examined more vigorously under innovative and alternative methodologies. In the increasingly complex and novel arenas in which the field now finds itself, those nontraditional methodological approaches could assist researchers in teasing out deeper levels of understandings of the field in order to help it to develop and serve its constituents. As such, this article presents the case for the application to IEL of such a novel methodology — comparative legal cultural analysis.

Among the more intractable and hidden barriers to IEL are legal cultural disconnects and discontinuities, obstacles that would be amenable to comparative legal cultural analyses. Legal cultural disconnects and discontinuities occur when opposing legal cultural characteristics from different legal cultures are forced to interact as part of the implementation of the law across two different legal cultures. While present in domestic legal systems, those conflicts are more likely and the conflicts may be deeper between the many different legal cultures involved in the international legal order. For example, legal cultural conflict is likely to arise in the interaction between traditional indigenous knowledge and the international intellectual property regimes. That discord may surface from, among other issues, the potential disconnect between the individualism present within the legal culture of international intellectual property and the collectivism found within many indigenous legal cultures. ${ }^{1}$ Identification of the relevant legal cultural characteristics can then permit solutions to be devised, permitting a more successful interaction between the participants from the different legal cultures.

Identification of such legal cultural disconnects and discontinuities is the first step towards developing strategies to ameliorate potential conflicts between opposing legal cultural characteristics. That identification requires examination of the relevant competing legal systems with legal culture in mind - a comparative legal cultural analysis. To the extent we do see legal cultural analyses, it is applied almost exclusively in the domestic arena. When it is applied across legal systems it becomes a part of comparative law methodology. But this merger of comparative law and legal cultural approaches is unusual, indeed almost unheard of in the IEL context. Nonetheless, this article will build the case for its application outside the domestic legal order and specifically for its utility in examinations of IEL.

\footnotetext{
${ }^{1}$ See, e.g., Lorie Graham \& Stephen McJohn, 'Indigenous Peoples and Intellectual Property', (2005) 19 Washington UJL \& Policy 313-337.
} 
Of course, any discussion of methodology takes place against the background that methodology in legal scholarship is both too little explored and an awkward area. ${ }^{2}$ Too often legal scholars simply "do" research without careful consideration of methodologies. ${ }^{3}$ Unlike the social sciences or many other intellectual fields, methodology is significantly missing as an explicit matter from much legal scholarship. It is often absent in the publications, frequently not receiving any mention at all, and it is seldom explicitly discussed by legal researchers. ${ }^{4}$ All too typically, legal researchers only confront legal research methodology when they do interdisciplinary work and the non-law participants press them for an explanation of the research methodology. When law scholars apply for grants they may also be asked for an explanation of their proposed research methodology. ${ }^{5}$ Such requests are often viewed with dread by legal researchers who then struggle to explain their methodology in an acceptable manner.

Comparative law, however, is one of the few areas of legal scholarship where methodology is regularly discussed and arguably constitutes a significant portion of the field. Indeed, some have considered comparative law to be merely a methodology, though the more accepted and modern view is that in addition to providing powerful research methodologies it also constitutes a field with substantive content. ${ }^{6}$ But, as discussed below, comparative law methodologies are almost exclusively applied to domestic law systems and are infrequently applied to international or transnational legal systems or institutions, especially not to IEL fields. Furthermore, for the reasons discussed below, on those rare occasions when comparative law is applied to the international legal order, though still producing useful results, it is typically applied in a limited manner. ${ }^{7}$ Rarely is a complete or holistic comparative analysis performed.

\footnotetext{
${ }^{2}$ While not the subject of this thesis, the reasons for the dearth of explicit methodological concern in legal research are not entirely understood, but thought to be connected to beliefs that: legal education typical fails to teach research methodology, beyond that required for the practice of law; law, in the common law world in particular, is less intellectually rigorous than other social science fields; the traditional sources of legal research (cases, statutes, etc) may not require complex methodological approaches; the supremacy of doctrinal research has stifled development of research methodological capability by researchers; and so on. This issue is presently the subject of research by the author, see also note 4 below. See also Section III.

${ }^{3}$ A recent UNSW Law Faculty research seminar, held 26 June 2012, focused on the question "Should legal scholars worry about research methodology?". The view that much legal research does not include consideration of research methdoology was one expressed by many of the academics present.

${ }^{4}$ Idibid.

${ }^{5}$ See, e.g., Australian Research Council Discovery - Instructions to Applicants for funding commencing in 2013, at 16, available at http://www.arc.gov.au/ncgp/dp/dp_instructions.htm (last accessed 11 January 2013).

${ }^{6}$ See generally, Mathias Reimann, 'The Progress and Failure of Comparative Law in the Second Half of the Twentieth Century', (2002) 50 American J Comparative L 671-700 (hereinafter "Reimann (Comparative Law)").

${ }^{7}$ Typically the few analyses that exist deal with quite specific issues, such as international criminal law, and in particular the International Criminal Court. See, e.g., Leila Nadya Sadat, 'The Nuremberg Paradox', (2010) 58 American J Comparative L 151-204; Robert Christensen, 'Getting to Peace by Reconciling Notions of Justice: The Importance of Considering Discrepancies Between Civil and Common Legal Systems in the Formation of the International Criminal Court', (2002) 6 UCLA J. Intl L \& Foreign Affairs 391-423; see also Rosa Ehrenreich Brooks, 'The New Imperialism: Violence, Norms, and the "Rule Of Law", (2003) 101 Michigan LR 2275-2340. Though, there are a few examples of the merger of comparative and international law. See, e.g., Mark W. Janis, 'Remark, Comparative Approaches to the Theory of International Law', (1986) 80 ASIL Procedings 152-175; David Kennedy, 'New Approaches to Comparative Law: Comparativism and International Governance', (1997) Utah LR 545-637; William E. Butler, 'International Law and the Comparative Method', in William E. Butler (ed.), International Law In Comparative Perspective (Sijthoff \& Noordhoff, Alphen aan den Rijn and Germantown, Maryland 1980) 25-40 . The
} 
Furthermore, a contextual comparative analysis, such as a comparative legal cultural analysis, is almost never undertaken. This article will refute the reasons and obstacles that stand in the way of comparative analyses of international law fields.

The article will first lay out the primary relevant methodological approaches for both international economic law and comparative law. The article will then present the proposed methodology, comparative legal cultural analysis, in the process necessarily first providing detailed consideration of the difficult concept of legal culture itself. Finally, the article will bring together these different methodological approaches as it argues for the employment of a comparative legal cultural analysis of international economic law. Given the constraints of a journal article, this article cannot provide detailed application of the methodology. However, it should be noted that direct application of the methodology has already been undertaken in a series of specific, but necessarily brief, case studies that have been very recently published or are shortly to appear in print. $^{8}$ Because those case studies focus on the direct implementations of the methodology there is correspondingly significantly less discussion of the background and bases of the methodology as are provided in this article.

\section{INTERNATIONAL ECONOMIC LAW RESEARCH METHODOLOGIES}

International economic law as a field is relatively new. ${ }^{9}$ Indeed, it is so new that it at times still faces existential challenges. ${ }^{10}$ While the individual components, such as trade, investment and finance, have been the subject of research for a long time, it is only in the last few decades that there has been vigorous and sustained research into these areas as individual parts of a connected field, each with their own, yet related, internal orders and

fact that one can list the primary examples within a footnote supports the assertion that it is a little used and developed methodology.

${ }^{8}$ Colin B. Picker, 'A Framework for Comparative Analyses of International Law and its Institutions: Using the Example of the World Trade Organization', in Eleanor Cashin Ritaine, Seán Patrick Donlan \& Martin Sychold (eds.), Comparative Law And Hybrid Legal Systems (Publicationof Swiss Institute of Comparative Law, 2010) (hereinafter "Picker (WTO)"); Colin B. Picker, 'Comparative Law Methodology \& American Legal Culture: Obstacles And Opportunities', (2011) 16 Roger Williams ULR 86-99 (hereinafter "Picker (RWU)"); Colin B. Picker, 'WTO Governance: A Legal Cultural Critique', in Kenji Hirashima (ed.), Governance In Contemporary Japan (Publication of University of Tokyo Institute Social Science, 2011) 103-124,; Colin B. Picker, 'International Trade and Development Law: A Legal Cultural Critique', (2011) 4(2) Law \& Development Review 43-71; Colin B. Picker, 'China, Global Governance \& Legal Culture', in Junji Nakagaw (ed.), China And Global Economic Governance: Ideas And Concepts (ISS Research Series No.45, Tokyo: Institute of Social Science, University of Tokyo., 2011) (hereinafter "Picker (China)"); Colin B. Picker, 'A Legal Cultural Analysis of Microtrade', (2012) 5(1) Law \& Development Review 101128; Colin B. Picker, 'Anti-Poverty v. The International Economic Legal Order? A Legal Cultural Critique' in Krista Shefer (ed.), Poverty \& The International Economic Law System (CUP, Cambridge 2013) (forthcoming); Colin B. Picker, 'Chapter 6, Microtrade and Legal Cultural Considerations' in Yong-Shik Lee (ed.), Microtrade: A New System Of International Trade With Volunteerism Towards Poverty Elimination (Routledge, 2013) (forthcoming).

${ }^{9}$ See generally Detlev F. Vagts, 'International Economic Law and the American Journal of International Law', (2006) 100 AJIL 769-782(citations omitted).

${ }^{10}$ See Steve Charnovitz, 'What is International Economic Law?', (2011) 3 J Intl Economic L 3-22 ("I have not been able to find even two definitions that match.”). 
approaches. ${ }^{11}$ Though, as such a new field, the exact contours and characteristics remain contentious and hidden, with very different views on what should be included within the field. Detlev Vagts notes:

'[IEL's] scope is controversial. According to one definition, it encompasses "the total range of norms (directly or indirectly based on treaties) of public international law with regard to transnational economic relations." A wide variety of international law rules have been said to have a financial impact somewhere. For practical purposes, ... I define international economic law as the international law regulating transborder transactions in goods, services, currency, investment, and intellectual property. I exclude from the inquiry issues of private international law, as well as of economic warfare. ${ }^{, 12}$

This article does not need to engage in the debate about the definition of the field, though those parts of IEL covered in this article do in fact conform to Vagts' definition of IEL.

Like public international law, which is considered to have an insufficient understanding of its theoretical and methodological bases, ${ }^{13}$ there is little agreement or understanding and, until recently, ${ }^{14}$ little work on innovative and novel IEL research methodologies. In part this is because IEL researchers would rather spend time discussing and presenting the results of their work, not how they researched those results. Thus, aside from the recent attention given to empirical methodologies, ${ }^{15}$ it is hard to persuade IEL academics to organize or take part in workshops or conference panels on methodological approaches. ${ }^{16}$ Nonetheless, occasionally a conference or book will buck the trend and delve into IEL methodology. One of the more accessible and holistic discussions on the subject are the works of Tomer Broude, Gregory Shaffer and Joel Trachtman presented at a conference that was organized with the explicit goal of seeking clarity on and understanding of the field of IEL as a whole. ${ }^{17}$ The products of that conference were then published in an edited collection. ${ }^{18}$ While other works exist, they are less precisely

\footnotetext{
${ }^{11}$ Tomer Broude, 'At the End of the Yellow Brick Road', in Colin B. Picker, Isabella D. Bunn \& Douglas W Arner (eds.), International Economic Law: The State and Future of the Discipline (2008) 15-28, 15.

${ }^{12}$ Vagts (fn 9) 769.

${ }^{13}$ Joel P. Trachtman, 'International Economic Law Research: A Taxonomy' in Colin B. Picker, Isabella D. Bunn \& Douglas Arner (eds.), International Economic Law-The State and Future of the Discipline (Hart, Portland 2008) 43-52, 45 .

${ }^{14}$ See, e.g., Amalya Perry-Kessaris (ed.), Socio-legal Approaches to International Economic Law: Text, Context, Subtext, (Routledge, London December 2012).

${ }^{15}$ See, e.g., Susan Franck, 'Empiricism \& International Law’, (2008) 48 Virginia J Intl L 767-815.

${ }^{16} \mathrm{My}$ experience as an organizer of numerous local, regional and global IEL conferences over the last decade has consistently found that formal discussion of methodology and teaching are typically eschewed by the vast bulk of researchers within the field.

${ }^{17}$ The American Society of International Law - IEL Group, Annual Conference: International Economic Law - The State and Future of the Discipline (9 November to 12November, 2006, held at the historic Mount Washington Resort at Bretton Woods, New Hampshire — birthplace of the IMF and World Bank).

${ }^{18}$ Colin B. Picker, Isabella D. Bunn \& Douglas Arner (eds.), International Economic Law - The State \& Future of the Discipline (Hart Publishing, Oxford 2008).
} 
focused on the methodology of the entire field. ${ }^{19}$ As such, the work of Broude, Shaffer and Trachtman that appear in that edited volume will be the primary sources here for this article's overview of IEL research methodologies.

The "bedrock" of IEL research methodology is traditional doctrinal analysis. ${ }^{20}$ As Trachtman notes, this reflects the practice orientation of legal education, "because practicing lawyers need not often argue about what the law should be, but are more concerned with what the law is, theory and methodology are unimportant." 21 Though, to the extent theory is present, it is a form of liberal economic theory, but then that theory is itself converted into "hard-nosed practical formulas" of the sort on which doctrinal analysis thrives. ${ }^{22}$ Broude, in discussing the continued relevance of this form of scholarship, even critiqued his own earlier work that employed that methodology as "ostrich-like, self centred, technical and legalistic".

Of course, other methodological research approaches do exist. Shaffer has argued that some of the other approaches in IEL research include "normative advocacy", "theoretical exposition" and empirical approaches. ${ }^{23}$ While empirical approaches are well understood and will not be further discussed or defined here, resort to Shaffer's terminology on the other two less well known descriptions is helpful. In normative advocacy

'[a]uthors writing in a normative vein typically advance a particular normative goal and then address how the institution, treaty or case law needs to be reformed, revised or interpreted to advance that normative goal. . . . The distinction of normative scholarship is that it explicitly aims to be transformative, while traditional legal formalist scholarship aims to be objective, purporting to describe law in neutral terms. ${ }^{24}$

In theoretical exposition "the scholarship does not constitute theory in a positivist sense in which theory signifies the making of propositions (or axioms) that can be tested and refuted, but rather puts forward a positive or normative analytic framework for understanding law."25 Shaffer's terminology is not exhaustive, with others describing similar approaches under different terms. Indeed, throughout legal methodological

\footnotetext{
${ }^{19}$ See, e.g., Issue 2, of (1994-95) 10 American J Intl 1 \& Policy 595-992, comprising a series of articles from a conference on Interdisciplinary Approaches to International Economic Law.

${ }^{20}$ Gregory Shaffer, ‘A New Legal Realism: Method in International Economic Law Scholarship' in Colin B. Picker, Isabella D. Bunn and Douglas Arner (eds.), International Economic Law-The State and Future of the Discipline (Hart, Portland 2008) 29-42, 30; Broude (fn 11) 24.

${ }^{21}$ Trachtman (fn 13) 46.

${ }^{22}$ Broude (fn 11) at 19.

${ }^{23}$ Shaffer (fn20) 31-33. Trachtman would have defined the range of methodologies somewhat differently, though in the main does not depart too far from those discussed by Shaffer above. The one exception, not relevant to the methodology at issue in this article, being Trachtman's greater discussion of the methodologies associated with public chocie theory, including law and economics. See Trachtman (fn13) 49.

${ }^{24}$ Shaffer (fn20) 31.

25 ibid.
} 
discussions one can find a proliferation of terms, with the taxonomy being confusing and suggestive of a plethora of approaches. Yet they often overlap or duplicate with other supposedly different methodological approaches. ${ }^{26}$ Nonetheless, Shaffer's terms are sufficient here, especially given their relevance to the methodology at issue in this article. Therefore, staying within his taxonomy, it can be said that doctrinal analysis remains the overarching approach for IEL, often supplemented by normative advocacy and qualitative or quantitative empirical research, yet with a theoretical framework likely included.

Of direct relevance to this article, Shaffer then strongly argues for a "new legal realist" approach which he claims would provide important insights into IEL — it "builds from the socio-legal tradition of "law and society' to engage in actual empirical work." 27 At times the exact content of that approach overlaps with the comparative legal cultural methodology discussed in this article. But, unlike comparative legal cultural analysis it does not employ comparative methodological techniques and approaches. Nonetheless, Shaffer does notes the vital role of legal culture in creating the legal reality central to his methodology. As an IEL scholar he even uses the World Trade Organization as an example for his proposal:

'[W]TO law does not exist in a separate, autonomous sphere - such as in the treaty texts or in the Appellate Body's adopted decisions - but operates within particular legal cultures in which these texts and decisions play a part. These legal cultures include the interaction of the WTO judicial process with those who bring arguments to it, on the one hand, and the national institutions and "civil society" to whom the judicial decisions are addressed, on the other. ${ }^{, 28}$

Shaffer's proposal is not the same as that presented in this article. In significant part because it does not delve deeply into the inevitable legal cultural clashes and disconnects. Nor does it employ comparative law to the extent found in the comparative legal cultural analysis proffered in this article. His suggestion nonetheless provides support for the idea that methodologies along his approach and that discussed in this proposal are legitimate methodologies for research in IEL. Indeed, Broude and others have argued for the employment of different and alternative approaches. ${ }^{29}$ Trachtman even argues that IEL researchers should go off in new directions specifically based on a better understanding of the many different and possible research methodologies:

'[w]e ... should recognize where our collective knowledge of a particular problem is adequate. One of the pathologies of IEL research, as of other law research, is to cover again ground that has already been covered. Greater understanding of, and agreement on, research methodology will allow us to form

\footnotetext{
${ }^{26}$ ibid 41 .

${ }^{27}$ ibid 38. While I have not had the chance to read it yet, a new book edited by Amanda Perry-Kessaris looks to be on point. See Perry-Kessaris (fn 14).

${ }^{28}$ ibid at 40.

${ }^{29}$ Broude (fn 11) 25-26.
} 
a consensus that certain issues are adequately known, and to go on to unknown issues. $^{30}$

That includes consideration of methodologies employed by non-law disciplines, though, Broude in particular notes that we risk leaving the law behind when we delve into nonlaw methodologies and are no longer "being jurists". 31 Thus, some efforts, such as those employing institutionalism, ${ }^{32}$ may be viewed as straying out of law and into sociology or other disciplines, though, of course, may still provide useful insights. But, comparative legal methodologies, as employed in this article, are firmly within the law and permit us to stay solidly on safe ground, even as they answer the challenge posed by the failures or inadequacies of traditional methodologies.

\section{COMPARATIVE LAW RESEARCH METHODOLOGIES}

Given that the methodology proposed in this article is drawn from and employs comparative methodologies, this section lays out the relevant foundations of comparative methodology. Furthermore, despite the lack of comparative law methodology in international law research, it is one of the central components in the intellectual inquiry into the law and as such will frequently be present even in methodologies that do not explicitly refer to it. Indeed, comparative law has played a critical role in the development of the law from ancient to modern times. Reputedly, Aristotle and Solon engaged in comparative consideration of other city-states' laws as they developed their theories on constitutions and law. ${ }^{33}$ More recently, the drafting of the Australian constitution at the end of the nineteenth century benefited from comparative considerations of other constitutions, such as that of the United States. ${ }^{34}$ In addition to helping develop the law, comparative law also permits greater understanding of one's own law, through reflection and understanding of other legal systems. ${ }^{35}$ But, the use of foreign systems as models or for self reflection cannot take place without methodologically appropriate examinations of those foreign legal systems. Comparative law methodology is the decisive tool in those efforts.

There is, of course, no "one" comparative law methodology. Indeed, there are numerous, sometimes contradictory, methodologies - from functionalism to the post modern

\footnotetext{
${ }^{30}$ Trachtman (fn 13) 43.

${ }^{31}$ Broude (fn 11) 26.

${ }^{32}$ See, e.g., Philip. M. Nichols, 'Forgotten Linkages-Historical Institutionalism and Sociological Institutionalism and Analysis of the World Trade Organization', (1998) 19(2) U Pennsylvania J Intl Economic L 461-511; Andrew T.F. Lang, 'Some Sociological Perspectives on International Institutions and the Trading System', in Colin B. Picker, Isabella D. Bunn \& Douglas Arner (eds.), International Economic Law - The State \& Future of the Discipline (Hart Publishing, Oxford 2008) 73-88.

${ }^{33}$ John H. Merryman, David S. Clark, \& John O. Haley, Comparative Law: Historical Development of the Civil Law Tradition in Europe, Latin America, and East Asia (Matthew Bender 1994) 1.

${ }^{34}$ See, e.g., William G Buss, 'Andrew Inglis Clark's Draft Constitution, Article III of the Australian Constitution, and the Assist from Article III of the Constitution of the United States', (2009) 33 Melbourne ULR 718-801.

${ }^{35}$ Vivian Grosswald Curran, 'Cultural Immersion, Difference and Categories in U.S. Comparative Law', (1998) 46 American J Comparative L 43-92, 46.
} 
contextualism to the post-post modern approaches. These different methodologies have generated conflict and disagreement between the adherents of the different approaches. Despite the complexities suggested by those different approaches, comparative analyses are something humans perform numerous times a day, albeit usually subconsciously. ${ }^{36}$ After all, when considering the differences between two people, we take into account the visible differences as well as their different abilities and characteristics - which in simplified form constitute the essential approaches of comparative analyses. But, even though it is an innate ability, a more formal consideration and application of the process both deserves attention and will improve any comparative analyses, ${ }^{37}$ no matter how basic.

One of the primary comparative law methods is "functionalism" — which argues that comparisons only make sense when what are being compared are functionally equivalent. ${ }^{38}$ In other words, that the legal issues compared are designed to address similar legal problems, regardless of differing names or other external characteristics. ${ }^{39}$ For example, the concept of third party participation in WTO litigation, through its use of the phrase "third party" may incorrectly suggest the rights, liabilities and procedures that exist with respect to third party defendants or complainants in domestic litigations. ${ }^{40}$ In some respects, functionalism addresses one of the more common comparative analytic errors, which is to compare things that appear similar but actually have different functions within the legal system.

It is especially difficult when working across legal systems that require linguistic and cultural translation as well as legal translation to ensure that comparable legal issues and problems are in fact being compared. ${ }^{41}$ Of course, aside from linguistic difficulties it can be hard to know truly whether things are similar or different, for the divergence between the comparables may only appear when each is combined or employed with another legal device. In other words, the function may only be understood in the context of the complete legal system or field within which it operates. Functionalism thus forms the backdrop against which comparative legal cultural analysis takes place. Thus, for example, in a comparative legal cultural analysis of governance at the WTO, an implicit

\footnotetext{
${ }^{36}$ The above discussion on comparative law methodologies in general is drawn from Colin B. Picker, 'Comparative Civil Procedure: Opportunities and Pitfalls', in Michael Legg (ed.), The Future of Dispute Resolution (LexisNexis Butterworths, Australia 2012) 247-256.

${ }^{37}$ Other non-functionalism errors and pitfalls that may ensue from comparative analyses are discussed in Colin B. Picker, Article 2, 'An Introduction to Comparative Analyses of International Organizations', in Lukas Heckendorn \& Colin Picker (eds.), Comparative Law and International Organizations: Cooperation, Competition And Connections (Publ. Of Swiss Institute of Comparative Law2013) (forthcoming) (hereinafter "Picker (IOs)").

${ }^{38}$ See generally, Ralf Michaels, 'The Functionalist Method of Comparative Law', in Mathias Reimann \& Reinhard Zimmermann (eds.), The Oxford Handbook of Comparative Law (OUP, Oxford 2006) 339.

${ }^{39}$ W. J. Kamba, 'Comparative Law: A Theoretical Framework', (1974) 23 ICLQ 485-519, 517.

${ }^{40}$ See, e.g., Xiaoming Pan, 'Developing Countries Participating As Third Parties in the WTO Dispute Settlement' (paper on file with author, presented at the Second Asia IEL Network Conference July 2011, University of Hong Kong Law Faculty) (suprisingly, the issue of third party rights in the WTO has received scant attention from scholars).

${ }^{41}$ See Curran (fn 35) 50 (1998); see also Janet E. Ainsworth, 'Categories and Culture: on the "Rectification of Names" in Comparative Law', (1996) 82 Cornell LR 19-42.
} 
functionalist analysis will take place permitting the discussion of "governance" to take place across different legal systems - from domestic to that of the WTO.

Common errors in functional analyses occur when there is a failure to understand:

That a foreign law may have no tangible function (it may be enacted for symbolic reasons) ${ }^{42}$;

That the function no longer continues to exist ${ }^{43}$;

That the function is not as anticipated or has changed ${ }^{44}$;

That the function is supplanted by an overarching ideology that supplants the legal issue ${ }^{45}$;

That there may be many different functions ${ }^{46}$.

In other words, functionalism can too easily be ethnocentric, viewing foreign legal issues through parochial lens. This is manifested in the basic expectation that functions can be similar and that problems in different legal systems are the same, felt the same, or understood the same way. ${ }^{47}$ In a comparative legal cultural analysis one would expect that the enhanced sensitivities should preclude such errors, but noting the common pitfalls can ensure the functional analysis is not inherently flawed.

Of course, there is no question that functionalism and the other comparative law methodologies engage in simplifications a great deal of the time. But, that is the norm in comparative law. ${ }^{48}$ Nonetheless, comparative law methodologies can be quite sophisticated and like all fields, comparative law and its methodologies continue to develop in ever more sophisticated and complex ways. The development of comparative law methodologies does not, of course, take place in a vacuum. Changes within the larger world of the law away from doctrinal rules and towards legal realism contributed to the move within comparative law away from traditional approaches, even when they were not incompatible, towards consideration of such new approaches as legal culture. ${ }^{49}$ Accordingly, and developed in some measure in response to comparative law's

${ }^{42}$ See Oliver Brand, 'Conceptual Comparisons: Towards a Coherent Methodology of Comparative Legal Studies', (2007) 32 Brooklyn J Intl L 405-466, 415.

43 ibid 419-20.

${ }^{44}$ See Christopher A. Whytock, 'Legal Origins, Functionalism, and the Future of Comparative Law', (2009) BYU LR 1879-1906, 1890.

45 See Brand (fn 42) 455.

${ }^{46}$ ibid 416.

${ }^{47}$ See Anne Peters \& Heiner Schwenke, 'Comparative Law Beyond Post-Modernism', (2000) 49 ICLQ 800-834, 820.

${ }^{48}$ See Reimann (Comparative Law) (fn 6) 677. ("First, it is understood today that all classifications are mere approximations to, not accurate reflections of, reality. We mostly continue to divide the world into civil law, common law, and several other systems but we know that these are ideal types which merely serve our need to maintain a rough overview.")

49 "Traditionally, the autonomy of the discipline of legal studies was located within the doctrinal rules, which were thought to be capable of generating solutions to every actual controversy." Paul W. Kahn, 'Freedom, Autonomy and the Cultural Study of the Law', in Austin Sarat \& Jonathan Simon (eds.), Cultural Analysis, Clutural Studies and the Law: Moving Beyond Legal Realism (Duke University Press, Durham and London 2003) 154-190, 155-56. 
traditional reliance on functionalism, comparative analyses increasingly focused on the comparative context—comparative contextualism. ${ }^{50}$

Contextualism is easily explained by considering that archetype of comparison- "apples and oranges". The differences between these fruits are vast, or so they appear in our ordinary life and use of those fruits. One is green or red, the other is orange; one is citrus the other is sweet; one needs to be peeled, the other has edible skin; one can be baked into a pie, the other can be preserved as a marmalade; one grows in semi-tropical climates, the other in colder regions; and so on. Those differences certainly suggest the two are not comparable - as is suggested by the traditional phrase. But, both are fruits, both are healthy snacks, both cost roughly the same, both are easily available in stores, and from a scientific perspective, they are almost indistinguishable. ${ }^{51}$ In those senses, they are similar. So, in addition to consideration of their function, their comparability depends on the context in which the comparison is being made-whether in the context of taste or cultivation.

For IEL, the contexts that are, as an initial matter, critical for comparative consideration are the institutional, constitutional, historical, political, and sometimes sociological and legal cultural contexts. Thus, the context of IEL must include not only what is written down, but as it is applied and as it is informed by history and the institutions within which it operates. Specifically, as argued in this article, IEL's context must also include consideration of the relevant and competing legal cultures - those of the international field, the international institutions and organizations, and those of the different domestic legal systems and communities involved in the IEL. Comparative legal cultural analyses are thus critical to understanding IEL's context.

\section{LEGAL CULTURE}

Before discussing comparative legal cultural analysis, the concept of legal culture itself must first be explored and explained - to the extent such an amorphous concept can be explained.

The relationship between law and culture has been the subject of inquiry and discussion for centuries:

'[Nineteenth century] scholars such as Maine and Savigny attributed the brilliance of Roman law to the fact that, for whatever reason, Roman culture

\footnotetext{
${ }^{50}$ Peters \& Schwenke (fn 47) 827.

${ }^{51}$ See Scott A. Sanford, ‘Apples and Oranges--A Comparison', 1 Annals of Improbable Research, May/June 1995, available at http:// www.improbable.com/airchives/paperair/volume1/v1i3/air-1-3-apples.html (last accessed 11 January 2013) (scientifically "apples and oranges are very similar"); see also Catherine Valcke, 'Comparative Law as Comparative Jurisprudence--The Comparability of Legal Systems’, (2004) 52 American J Comparative L 713-740, 720 (noting the comparability of apples and oranges in the context of comparing legal systems).
} 
glorified jurists who, for a long period of time, were dedicated to the aim of continually improving Rome's legal institutions.' 52

Similarly, legal culture is apparent in Montesquieu's eighteenth century declaration in $D e$ l'Esprit des Lois where he claimed that law depended on "local conditions". 53 Also, as an expression of the role of legal culture, the highly influential nineteenth century German historical school:

'[C]onsidered law to be the manifestation of the people's national spirit ("Volksgeist") and thereby particular to every nation--an organic product of society which has to be watched for and discovered, rather than made or tampered with. ${ }^{54}$

Nonetheless, despite its solid heritage, legal culture is an elusive concept. ${ }^{55}$ While the notions associated with legal culture are to some scholars vague and close to impossible to use, they are critical and imperative for others. These differences, whether real or imagined, ${ }^{56}$ exist despite the fact that there are no shortages of definitions of legal culture. For example:

'[B]y "legal culture," we mean the patterns of order that shape people, institutions, and the society in a jurisdiction. ${ }^{57}$

'[T]he most significant feature of legal cultures would be the styles of argumentation in jurisprudence. 58

\footnotetext{
${ }^{52}$ Kevin E. Davis and Michael J. Trebilcock, 'The Relationship Between Law and Development: Optimists Versus Skeptics', (2008) 56 American J Comparative L895-946.

${ }^{53}$ See Brand (fn 42) 430 (citing Montesquieu, The SpIRIT OF LAws 103-05 (David Wallace Carrithers trans., U. Cal. Press) (1977)).

${ }^{54}$ ibid 430.

${ }^{55}$ See Austin Sarat \& Jonathan Simon, 'Cultural Analysis, Cultural Studies and the Situation of Legal Studies', in Austin Sarat \& Jonathan Simon (eds.), Cultural Analysis, Cultural Studies, and the Law: Moving Beyond Legal Realism (Duke University Press, Duhram and London 2003) 1-37, 12.
}

${ }^{56}$ Amy Cohen reports that Peter Fitzpatrick has argued that "that many definitional debates about culture split along the following lines: culture is claimed to be determinate, reified, and stable or foundationally indeterminate, dynamic, and riddled with fissures and internal dissent. Fitzpatrick, however, reasons that " "[d]espite the seeming opposition between these [two dimensions], culture has to be in a sense both.' He is moved to this conclusion by the myriad ways in which people interact with their own and other 'cultures,' producing both consistency and change." Amy J. Cohen, 'Thinking with Culture in Law and Development', (2009) 57 Buffalo LR 511-586, 543 (quoting from a paper in Cohen's records, entitled Peter Fitzpatrick, Costs of Culture 1 (unpublished paper prepared for the Law and Society Annual Meeting, Humboldt University, Berlin (28 July 2007)) and also quoting from Peter Fitzpatrick, 'The damned word": Culture and its (In)compatibility with Law', (2005) 1 LAw, CUlTure, \& HuMAN 2-13, 11.

${ }^{57}$ Bernhard Grossfeld and Edward J. Eberle, 'Patterns of Order in Comparative Law: Discovering and Decoding Invisible Powers’, (2003) 38 Texas Intl LJ 291-316, 292.

${ }^{58}$ Erhard Blankenburg, 'Patterns of Legal Culture: The Netherlands Compared to Neighboring Germany', (1998) 46 American J Comparative L1-41, 40 (citing René David, in InTroduction, II InTERNATIONAL ENCYCLOPEDIA OF COMPARATIVE LAW (1972)). 
'[A]nthropologists ... interpret legal culture as a local phenomenon, shaped by local knowledge and practice, through which symbols such as "law" or "court," understandings of "rights" and "wrongs," and concepts of "crime," of "normal trouble" or of complaining and dispute take on particular, locally relevant meanings. In an interpretive account, legal culture not only differs in different contexts, but law is "invented", negotiated, or "made" in local settings., 59

Cultural studies of the law fulfil the "need to investigate the ways in which law is constitutive of group and individual identities and values". ${ }^{60}$

Legal culture "refers to ideas, values, expectations and attitudes towards law and legal institutions, which some public or some part of the public holds."

'[B]y "legal culture" is meant those historically conditioned, deeply rooted attitudes about the nature of law and about the proper structure and operation of a legal system that are at large in the society. ${ }^{62}$

'[C]ulturalists essentially contend that legal rules are embedded in local dimensions of the law. Each legal culture is a unique, culturally contingent product, which is incommensurable and untranslatable except through a deep understanding of the surrounding social context. ${ }^{, 63}$

Much of the cultural studies of law movement has been an effort to shift the location at which we study law from the opinions of the appellate courts to the expressions of ordinary people carrying out the tasks of everyday life. ${ }^{64}$

'[T]he creation of legal meaning - 'jurisgenesis' - takes place always through an essentially cultural medium. ${ }^{65}$

While not defined explicitly as legal culture, comparatist Ed Eberle describes what is otherwise legal culture:

' $[\mathrm{N}]$ ot all external law is written. A second, deeper part of law lies beneath the surface and is less visible. These are the underlying forces that operate within a society to help form and influence law and give it substance. We might call this

\footnotetext{
${ }^{59}$ Barbara Yngvesson, 'Inventing Law in Local Settings: Rethinking Popular Legal Culture', (1989) 98 YALE LJ 16891709, 1690(citation omitted)

${ }^{60}$ Kahn (fn 49) 162.

${ }^{61}$ Lawrence M. Friedman, 'The Concept of Legal Culture: A Reply', in David Nelken (ed.), Comparative Legal Cultures (Aldershot: Dartmouth 1997) 33-40, 34.

${ }^{62}$ Merryman (fn 33) 51.

${ }^{63}$ Brand (fn 42) 428.

${ }^{64}$ Kahn (fn 49) 155.

${ }^{65}$ Robert M. Cover, 'Foreword: Nomos and Narrative', (1983) 97 Harvard LR 4-68, 11.
} 
the "invisible" dimension of law. Not that this dimension is wholly unknown or unrecognizable, but more that this dimension of law is one we tend to assume, take for granted, or perceive just dimly. Or we might think of these invisible patterns as underlying crypto types-" the pattern to be revealed - or legal formants-" non-verbalized rule[s]" - or "implicit patterns." Or we might think of this dimension as "substructural, often unarticulated, categorizations. ..." We might refer to this dimension of law as internal: forces that operate beneath the surface of external law, but which infuse the law with meaningful content. ${ }^{, 66}$

Clearly the concept of legal culture has a rich and long history in the literature, and yet may be thought to fall short in fully explaining the concept in a tangible and manageable fashion.

In this article, as was employed in the related case study articles, a more simple and functional definition, grounded in comparative law, will be offered. Namely that legal culture is defined:

to consist of those characteristics present in a legal system, reflecting the common history, traditions, outlook and approach of that system. Those characteristics may be reflected in the actions or behaviours of the actors, organizations, and even of the substance of the system. Legal culture exists not because of regulation of substantive law, but as a result of the collective response and actions of those participants in the legal system. As a result, legal culture can vary dramatically from country to country, even when the countries share a common legal tradition. Critically, legal culture is also to be found within international organizations and fields - for they too are legal systems. Those different legal cultures are critical for understanding the legal systems, for different legal cultures tell different stories, ${ }^{67}$ see the world differently, and project different visions. ${ }^{68}$

But, legal culture should also be differentiated from legal traditions and legal systems. Legal systems are "the composite of the legal organizations, rules, laws, regulations, and legal actors of specific political units--usually states or sub-state entities[- - and] have largely the same characteristics[,] the same rules and organizations. ${ }^{69}$ Legal traditions, in contrast, are:

'[f] amilies of legal systems, sometimes . . . legal models or patterns . . [but] a legal tradition is not a synonym for the history or development of law in a given country[, r]ather, it is the aggregate of development of legal organizations (in the

\footnotetext{
${ }^{66}$ Edward J. Eberle, 'The Methodology of Comparative Law', (2011) 16 Roger WiLliams ULR 51-72, 63 (citations omitted).

${ }^{67}$ See Mary Ann Glendon, Abortion and Divorce in Western Law (Harvard University Press, Harvard 1987) at 8.

${ }^{68}$ See Picker (China) (fn 8) 72-73 (citations omitted).

${ }^{69}$ Colin B. Picker, 'International Law's Mixed Heritage: A Common/Civil Law Jurisdiction', (2008) 41 VANDERBILT J Transnational L 1093-1140, 1094 (hereinafter "Picker (International)").
} 
broadest sense of the term) in a number of countries sharing some fundamental similarities in the law. ${ }^{, 70}$

Thus, one can see that while similar, and often confused and at times interchangeable in some comparative analyses, the critical issue that differentiates a comparative legal cultural analysis is that legal culture is more informal, subconscious, and typically tied to just one system's legal actors. In contrast legal systems are more formal and their characteristics are consciously created and applied, while legal traditions normally typically describe broad groupings and more typically reflect formal sources of law.

Perhaps most critically, in contrast to the concept of legal traditions, legal culture reflects the "living law" in one legal system or community, focusing on the behaviour of the participants. Legal traditions may set the environmental factors for those participants, but how those participants behave within those legal settings is a matter of legal culture, not legal tradition, though legal tradition may play a role in shaping that legal culture. Indeed, as Erhard Blankenburg notes " $[\mathrm{t}]$ he comparison of Dutch and German legal institutions has shown that similarities of formal legal systems are bad predictors of how legal cultures actually work." 71 A similar example showing the lack of congruence between tradition and culture are the very different legal cultures in England and the United States - both members of the Common Law tradition.

Thus, legal systems belong to overarching legal traditions, while legal cultures exist within, and sometimes across, legal systems, completely or partially within the overarching legal traditions. There are legal cultures associated with legal traditions, geographic regions, legal systems, legal fields, and even associated with communities, large and small. For example, we can talk about the legal culture of the Socialist legal tradition, of Western Europe, of the WTO, of international investment law, of France, of family law, of the Amish community, or even of the Hell's Angels. The discussion of those legal cultures will be different, varying at each level, likely to be more generalized, diffuse and vague for the larger bodies or fields, yet likely to be very specific and detailed for the smaller focused communities or fields. But, whatever the legal or geographic jurisdiction to which the legal culture applies, it will be the case that the legal culture resides in the conscious and subconscious behaviours and attitudes of the many different participants within that jurisdiction - from clients to lawyers, from judges to jurors, from citizens to politicians, from bike gang leader to family law professors.

It should be noted, however, that complete legal cultures should be differentiated from the more specific legal cultural characteristics found within those legal cultures, and which comprise the data in most comparative legal cultural analyses. It is the latter therefore, the legal cultural characteristics, which are typically at issue in those analyses - the heart of this article's proposal. After all, it is rare for an entire legal culture to be in opposition to another legal culture or to an international policy initiative.

\footnotetext{
${ }^{70}$ Ugo Mattei, 'The Art and Science of Critical Scholarship: Postmodernism and International Style in the Legal Architecture of Europe', (2001) 75 Tulane LR 1053-1091. (text at fn 68) (citations omitted).

${ }^{71}$ Blankenburg (fn 58) 39.
} 
The relevant issues are thus the specific legal cultural characteristics within the larger legal culture. Legal cultures as a whole would typically be too large, amorphous and unwieldy to be very helpful when considered in the aggregate. Nonetheless, there may sometimes be benefit to considering a legal culture in the aggregate, such as when considering the overall fit of one legal system with another. Because legal cultures in the aggregate are not discussed in detail in the remainder of this article, a brief description of such an aggregate legal culture may be helpful (in addition, as the discussion below shows, the examination quickly devolves to consideration of specific legal cultural characteristics). For that example, as it is the American legal system that is often portrayed as being the outlier in international law, ${ }^{72}$ this article will briefly discuss that aggregated legal culture as a concrete, albeit generalized example of a legal culture.

Regardless of its utility or accuracy, we can speak of the legal culture that exists as a general matter across the entire United States - as an overlay under which the many legal subcultures are found and through which the American legal system operates. But, that legal culture is really just an aggregation of the many different, sometimes contradictory, sometimes connected, legal cultural characteristics found throughout the United States (thus, once again, it is necessary to return to specific legal cultural characteristics). The American legal culture may be said to include, among many others, the following legal cultural characteristics: individualism; pragmatism; parochialism; localism; nationalism; exceptionalism; messianism; legal minimalism; public participation; legal scepticism; legal realism; market force orientation; positivism; religious overtones; constitutional cultism; instrumentalism; utilitarianism; extreme adversarialism; and so on. ${ }^{73}$ The extent and depth of these legal cultural characteristics is, of course, debatable. While, many of them may be found in other legal cultures, it is the aggregate of these and other American legal cultural characteristics that comprises the American legal culture.

Furthermore, in keeping with the definition of legal culture, those characteristics are not mandated by the formal parts of the American legal system or by the legacy of the common law tradition. After all, statute, regulations, case law, or the overarching legal tradition are not the determinates of a legal culture, though they may reflect and influence the legal culture and hence may help to maintain that legal culture. For example, in America the rules of discovery create the conditions for the abusive discovery that has become a part of the American legal cultural landscape, yet those rules do not mandate that sort of behaviour. ${ }^{74}$ The legal culture leads to those patterns of behaviour. In other words, that American legal culture is not instilled through formal means-through regulation or other official means. In significant respects, it is transmitted through American popular culture and through the American people's collective observations of

\footnotetext{
${ }^{72}$ See, e.g., Colin B. Picker, 'Reputational Fallacies in International Law: A Comparative Review of United States and Canadian Trade Actions', (2004) 30 Brooklyn J Intl L 67-116.

${ }^{73}$ These observed legal cultural characteristics are based on my experiences in America as a law student, judicial clerk, attorney and as an academic, teaching American law (in America and overseas). See also, Kimberlianne Podlas, 'Homerus Lex: Investigating American Legal Culture Through the Lens of the Simpsons', (2007) 17 Seton Hall J Sports \& Entertainment L 93-133 (humorous but very insightful examination of American legal culture).

${ }^{74}$ See, e.g., U.S. Federal Rules of Civil Procedure, Rule 26 et seq.; see especially Rule 26(b)(2)(C) (rules suggesting limits when abusive).
} 
the way members of the public and the legal profession behave and respond to legal issues. The professionals within the legal system are further exposed to the overarching legal culture during their legal education and subsequent legal practice. Thus, American law students early on "pick up" that there is an expectation, not mandated by law, that as practitioners they will provide free, pro bono, legal service to worthy causes. ${ }^{75}$ Similarly, once in practice, new American lawyers find out that despite stringent state bar rules to the contrary, they can be expected as a de facto matter to practice the law of other state jurisdictions - to be "American" and not just local lawyers. ${ }^{76}$ Thus, legal culture while highly informal can be very powerful in creating the "living law" of a legal system.

Though not the subject of this article, considerations of the American legal culture as a whole and its fit with the legal culture of international law or its subparts could be a fruitful line of inquiry. But, that consideration will have to wait for another day. This article is concerned with developing and explaining a methodology that deals with international legal cultural conflicts that may arise between legal cultural characteristics of different legal systems, including international legal systems such as that of IEL.

\section{COMPARATIVE LEGAL CULTURAL ANALYSIS}

Comparative legal cultural analysis is the crux of this proposal. Put simply, a legal cultural analysis of a legal system or community involves identifying those legal cultural characteristics which play a significant role in the development of that legal system or community, both internally and, in its comparative flavour, in its interactions with outside legal systems and/or communities.

In considering the non-mandated behaviours of legal participants, comparative legal cultural analysis overlaps to some extent with some other realist legal analyses, including "socio-legal" analyses, such as that undertaken by Moshe Hirsch. ${ }^{77}$ There may also be some overlap with legal anthropology, especially when the legal cultural analysis is more descriptive. ${ }^{78}$ While the comparative legal cultural analysis suggested in this article is not ethnography, it is nonetheless akin to those analyses that seek a "thick description" of the relationship between culture and law. ${ }^{79}$ A "thick description" gives

'[a] complex account of the slippage between the production and reception of law and legal meanings, of the ways in which specific cultural practices or identities

\footnotetext{
${ }^{75}$ See, e.g., Leslie C. Levin, 'Pro Bono Publico in a Parallel Universe: The Meaning of Pro Bono in Solo and Small Law Firms', (2009) 37 Hofstra LR 699-734, 703.

${ }^{76}$ Arthur F. Greenbaum, 'Multijurisdictional Practice and the Influence of Model Rule of Professional Conduct 5.5 -An Interim Assessment', (2010) 43 Akron LR 729-768.

77 See, e.g., Moshe Hirsch, 'The Sociology of International Economic Law', (2008) 19 European J Intl L 277-299.

${ }^{78}$ See Naomi Mezey, 'Law as Culture', in Austin Sarat and Jonathan Simon (eds.), Cultural Analysis, Cultural Studies, and the Law: Moving Beyond Legal Realism (Duke University Press, Duhram and London 2003) 37-72, 58.

79 See Clifford Geertz, 'Thick Description: Toward an Interpretive Theory of Culture', in Clifford Geertz, The Interpretation of Culture: Selected Essays (1973) (Basic Books, New York 1973).
} 
coincide or collide with specific legal rules or conventions thereby altering the meaning of both.' 80

But, in this article legal culture it is not used just in a thick descriptive or thin interpretive manner, as is the case in cultural anthropology. ${ }^{81}$ The goal here is additionally the eventual application and utility of the underlying law related to the legal cultures at issue as well as examination of the real world interactions between legal systems and their participants. Thus, this article focuses not just on legal culture and its role in legal conflicts and disputes, but also on the relationship of legal culture with the other tangible work of the law, from transactions to the creation of international economic realities in trade, investment or other IEL fields.

Furthermore, the comparative legal cultural analyses suggested in this article is not the same as these other methodologies for there will be a greater connection to comparative law within the analyses, which would not have been the case for these other methodologies. A few comparative examples of legal culture and its relationship to different parts of the international economic legal order may help illustrate the point.

For example, the manner in which disputes have been resolved between the members of the Association of Southeast Asian Nations very strongly reflects certain common legal cultural characteristics, such as " finessing' and 'defusing"” being "preferred to adversarialism and confrontation". ${ }^{82}$ The reference to adversarialism can immediately tie into many concepts within comparative law, ${ }^{83}$ thus leading to numerous additional insights related to those legal cultural characteristics and legal systems and institutions.

Similarly, the litigiousness of a state, a key legal cultural characteristic, has been found to be reflected in the state's tendency to file cases at the WTO. ${ }^{84}$ Litigiousness has been examined extensively in comparative law $^{85}$ and employing the lessons from those examinations can lead to insights relevant to that legal cultural characteristic and used to expand our understanding of that legal culture and the WTO.

\footnotetext{
${ }^{80}$ See Mezey (fn 78) 54.

${ }^{81}$ ibid 56. Nor are Paul Kahn's four methodological approaches applied here, for they concern other aspects of the cultural study of the law, more theoretical than utilitarian in the direct manner applied throughout this disertation. See 'Article 3, Methodological Rules' in Paul W. Khan, The Cultural Study of the Law: Reconstructing Legal Scholarship (the University of Chicago Press, Chicago 1999) (hereinafter "Kahn (Book)") 91-127.

${ }^{82}$ Lisa Toohey, 'When 'Failure' Indicates Success: Understanding Trade Disputes Between ASEAN Members' in Ross Buckley, Richard Weixing Hu \& Douglas W. Arner (eds.), East Asian Economic Integration: Finance, Law and Trade (Edward Elgar Pub 2011) 150-182, 178.

${ }^{83}$ See, e.g., Picker (WTO) (fn 6).

${ }^{84} \mathrm{Ji} \mathrm{Li}$, "See You in Court!" to "See You in Geneva!": An Empirical Study of the Role of Social Norms in International Trade Dispute Resolution', (2007) 32 Yale J Intl L 485-516 (while an excellent empirical analysis, this particular study would have been greatly improved through inclusion of comparative and specifically legal cultural analyses).

${ }^{85}$ See, e.g., J. Mark Ramseyer, 'The Costs of the Consensual Myth: Anti-Trust Enforcement and Institutional Barriers to Litigation in Japan', (1985) 94 Yale LJ 604-645, 610.
} 
Nonetheless, legal cultural analyses are difficult and awkward-hence their general absence from IEL research. Indeed, despite the existence of numerous attempts to define and categorize legal culture, examples of which were provided earlier in this article, there remains a great deal of scepticism about the concept, even outside of the international and IEL context. Roger Cotterrell, for example, notes that: "the imprecision of these formulations makes it hard to see what exactly the concept covers and what the relationship is between the various elements said to be included within its scope." 86 But, Cotterrell concedes that it is nonetheless useful "for its emphasis on the sheer complexity and diversity of the social matrix in which contemporary state legal systems exist." ${ }^{, 87}$ Of course, legal culture analysis shares many of the same vagueness problems as exists with studies involving culture in general. As Oscar Chase notes: "The principal difficulties spring from the inherent vagueness of the concept, its potentially misleading message of immutability of practice and belief, and its failure to acknowledge individual departures from, and even opposition to, a social orthodoxy". ${ }^{88}$ Chase then does acknowledge that "these problems do not trump the utility of the concept of culture as a short-hand way of acknowledging commonalities in practices, values, symbols and beliefs of groups of people that form some sort of collectivity." 89

In addition, comparative legal cultural analyses may also be subject to many of the same criticisms frequently levelled at other contextual approaches within comparative methodology. Those contentious could potentially chill the application of the methodology outside its usual arena. ${ }^{90}$ But, those disagreements are often not relevant outside the very academic arguments in which they are found and generally not relevant to the very real world practical applications of comparative legal cultural analyses. As an initial matter, comparative legal cultural analyses must confront the post modern critique that true comparative law is not possible due to the fact that comparatists cannot escape their own legal culture in order to sufficiently "enter" that of another legal system. ${ }^{91}$ After all, "a valid examination of another legal culture requires immersion into the political, historical, economic and linguistic contexts that moulded the legal system, and in which the legal system operates." 92 But, whether impossible or not with respect to comparative analyses of domestic legal systems, the overall subject of the methodology proposed in this article is an international legal system-IEL. Immersion into a field of international law is not generally contemplated by those comparatists arguing this issue and may not even be relevant to the discussion! After all, international law fields occupy a space across all legal systems and are everywhere, including within the many different

\footnotetext{
${ }^{86}$ Roger Cotterrell, 'The Concept of Legal Culture', in David Nelken (ed.), Comparing Legal Cultures (Aldershot, Dartmouth 1997) 13-31, 15 .

${ }^{87}$ ibid 29.

${ }^{88}$ Oscar G. Chase, 'American "Exceptionalism” and Comparative Procedure', (2002) 50 American J Comparative L 277-301, 278-79.

${ }^{89}$ ibid 278-79.

${ }^{90}$ See Peters \& Schwenke (fn 47).

${ }^{91}$ Curran (fn 35) 48-49.

92 ibid 51.
} 
domestic legal systems. They are fundamentally different to the geographically and politically bounded domestic systems typically considered by those seeking immersion into a foreign legal culture. To the extent international legal fields and institutions include a legal culture, which this article does indeed suggest, then those legal cultures are not closed, but open to participants from all systems equally, with each contributing to the formation of the legal culture of the international institution or field. As such, the outsider comparatist has the ability to immerse herself into the subject legal culture as easily as any of the many different participants from the numerous different domestic legal systems that participate in the institution or field. True, there are factors, accessible to all with sufficient preparation, that will assist in that immersion. They include language, educational and professional experiences, legal tradition background and so on-all factors that should be considered by a researcher when embarking on a comparative legal cultural analysis of an international field or institution. Of course, when analysing the legal culture of any relevant domestic systems, legal cultural analysis does enter the terrain governed by the "inability to immerse" critique. But, because the comparative legal cultural analysis is not intended to understand or analyse the complete domestic legal systems at issue, the issue of incomplete immersion is perhaps not as present, certainly not present to such a degree to rule out the analysis. Furthermore, because multiple domestic legal systems may be relevant to the international legal system under examination, full immersion into all of them is perhaps an unattainable goal outside the context of a vast team of researchers all working together. Hence, while the critique should be noted and taken into account as much as possible, it cannot stand as an obstacle if comparative legal cultural analyses are to be undertaken.

Like comparative law methodologies in general, comparative legal cultural analysis must be able to respond to post-modernist critiques. The proposed methodology does not fit well with the extreme positions found among some of the post-modernists, such as those associated with epistemic and moral relativism positions. ${ }^{93}$ Rather, this work may best fit with the post-post modernists within comparative law.

'[A] post-post-modernist approach to comparative law will retain the (self)critical impetus of the post-modernist critique, reject the postmodernist assertion that objectivity is not attainable in comparative law, and synthesise old and new demands for interdisciplinarity and thoughtful hermeneutics. 94

Nonetheless, the methodology is generally not concerned with the validity or otherwise of one comparative methodology over another. It can operate within the assumption that the traditional, modern and post-modern methodologies and bases of comparative law, especially that of functionalism, are important and insightful approaches.

Similarly, the methodology proposed here does not need to be considered alongside or within the arguments concerning the impossibility of legal transplantation, a position well

\footnotetext{
${ }^{93}$ Peters and Schwenke (fn 47) 813.

94 ibid 829-32, 829.
} 
argued by Pierre Legrande in numerous works. ${ }^{95}$ As an initial matter, the methodology is not primarily concerned with the transplantation of law from one domestic system to another. Rather, here the concern is with the relationships between international law, international organizations and domestic legal systems - but only insofar as that domestic law is relevant to the international organization, the international law, or the domestically implemented international law. Nonetheless, transplantation is relevant to some aspects of the article, but the fact that legal cultural analyses are involved serves to mitigate Legrande's critique of the typical academic discussions of transplantation. His essential argument is that transplantation efforts are inherently flawed, for imported law that is itself culturally anchored to a foreign system cannot be imported into a legal system that

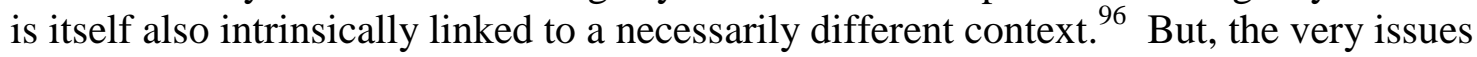
that Legrande raises, are the very issues examined here even as they may be absent in the typical works involving legal transplantation. As such, there is no need for the article to confront Legrande's critique, for that critique is already a part of the very fabric of the article.

Comparative law can be difficult and rife with substantive, methodological and theoretical pitfalls. For the most part, the debates about methodology within comparative law are simply not relevant to the methodology proposed in this article. But, because of the definitional and vagueness issues, legal culture analyses can still be awkward and misunderstood, and consequently ignored or minimized within the already contentious and difficult comparative law. It is thus no surprise that comparative and legal cultural analyses are hardly applied outside the usual domestic legal system subjects that form the primary arena of comparative law. As such, this article's application of comparative and comparative legal cultural analyses to an international law field, IEL, pushes the bounds of those methodologies.

\section{COMPARATIVE AND LEGAL CULTURAL ANALYSIS OF INTERNATIONAL LAW AND INTERNATIONAL ECONOMIC LAW}

Trachtman rightly notes that "each research method has a domain in which it is illuminating. Outside that domain, it may be misleading."97 But, the domain of comparative law methodologies can, as this article seeks to show, be extended to include international fields. Indeed, some scholars at the micro level have with some success employed aspects of comparative law to examine discreet areas of international law. ${ }^{98}$ Though, for the most part, scholars either ignore or fail to use comparative methodologies

\footnotetext{
${ }^{95}$ See, e.g., Pierre Legrande, 'What “Legal Transplants"?' in David Nelken \& Johannes Feest (eds.), Adapting Legal Cultures (Hart Publishing, Oxford 2001) 55-70.

96 ibid 60-65.

${ }^{97}$ Trachtman (fn 13) 44.

${ }^{98}$ See note 7 above.
} 
to examine international law fields - especially at a macro level. ${ }^{99}$ But, it is possibleand potentially fruitful. For example, one of the background works to this article provided a unique comparative analysis of public international law as a whole. ${ }^{100}$ That examination approached international law through the classic western comparative law taxonomy, identifying common and civil law characteristics that exist within international law. It came to the conclusion that public international law is predominantly a mix of characteristics that derive from the civilian and common law traditions, and furthermore that the nature of the mix bears substantial similarity to those jurisdictions known as "mixed jurisdictions". ${ }^{101}$ That conclusion suggests that the ongoing development of public international law may benefit from consideration of how the similar mixed jurisdictions have successfully handled the mix of common and civil law components of their legal systems.

Nonetheless, despite the utility of such works there is scepticism within the public international law field that comparative law drawn from the domestic arena is relevant to what is often considered to be the unique international law system. ${ }^{102}$ Even aside from any notions of uniqueness, international law research tends to shy away from comparative law methodologies. ${ }^{103}$ An uncharitable explanation could be that it is due in part to international law's parochial and superior nature. ${ }^{104}$ Indeed, while referring to domestic systems, and there is little to suggest it is not as applicable to international systems, Karl Llewellyn noted that:

"[N]owhere more than in law do you need armor against . . . ethnocentric and chronocentric snobbery-the smugness of [one's] own tribe and [one's] own time: We are the Greeks, all others are barbarians."

As such, international law research will too often see little value in domestic legal systems - despite the clear domestic law heritage of much of international law. ${ }^{106}$

\footnotetext{
${ }^{99}$ See Valentina Vadi, 'Critical Comparisons: The Role of Comparative Law in Investment Treaty Arbitration', (2010) 39 Denver J Intl L \& Policy 67-100 ("Comparativists and internationalists alike have almost entirely neglected the interaction between international law and comparative law.”).

${ }^{100}$ See Picker (International Law) (fn 69).

${ }^{101}$ Mixed jurisdictions were first defined more than one hundred years ago as "legal systems in which the Romano-Germanic tradition has become suffused to some degree by Anglo-American law." William Tetley, 'Mixed Jurisdictions: Common Law v. Civil Law (Codified and Uncodified)', (2000) 60 Louisiana LR 677-738, 679 (citations omitted); see also Vernon Valentine Palmer (ed.), Mixed Jurisdictions Worldwide: The Third Legal Family ( CUP, Cambridge 2001).

${ }^{102}$ See Aleksandar Momirov \& Andria Naudé Fourie, 'Vertical Comparative Law Methods: Tools for Conceptualising the International Rule of Law’, (2009) 2 Erasmus LR 291-310, 296.

${ }^{103}$ See Jaye Ellis, 'General Principles and Comparative Law', (2011) 22 European J Intl L 949-971; but see Charles H. Koch, Jr., 'Envisioning a Global Legal Culture', (2003) 25 Michigan J Intl L 1-76 (though, the article is more focused on identifying some future collective global legal culture).

${ }^{104}$ See, e.g., ibid 4. Such attitudes are found in other large legal (and small) legal systems as well. See also Picker (RWU), supra note 8.

${ }^{105}$ K. N. Llewellyn, The Bramble Bush 42-43 (7th prtg. Ocena Publications, New York 1981).

${ }^{106}$ See Picker (International Law) (fn 69).
} 
If there has been little use of comparative law methodologies within general international law research it should not then be surprising that the relatively more hard-nosed economics-based field of IEL also typically fails to utilize comparative law methodologies. ${ }^{107}$ Also, comparative legal cultural analyses, the methodology suggested here, as a more difficult and unusual comparative method, is even more rarely considered within international law. ${ }^{108}$ While sometimes noted, ${ }^{109}$ it is rarely considered in depth, despite research that points to the need for such legal cultural analyses. ${ }^{110}$

But, the blame for the lack of comparative and comparative legal cultural analyses of international law, to the extent blame is relevant, cannot just be laid at the feet of international law researchers. Comparatists have also been reluctant to apply themselves to international issues. ${ }^{111}$ Indeed, traditional comparative analyses are often attacked "for isolationism vis-á-vis related legal subjects (such as jurisprudence or international law) and for lack of interdisciplinary efforts" and "for persistent Eurocentrism and obsession with private law; as well as for lack of attention to international regimes". ${ }^{112}$ Though there are some efforts, especially within the last few years, when comparatists have tackled international law issues, most often those works relate to those times when international and national have concurrent jurisdiction. ${ }^{113}$ But, it is clear that there is a need for more comparatists to consider international law fields and institutions, and within their comparative analyses to apply some of the less traditional methodologies, such as comparative legal cultural analyses. ${ }^{114}$ Though, it should be noted that even within comparative law's consideration of domestic systems, legal cultures are not always formally acknowledged. After all, legal cultural analyses has often been carried

\footnotetext{
${ }^{107}$ See Section III above.

${ }^{108}$ David Kennedy, 'New Approaches to Comparative Law: Comparativism and International Governance', (1997) Utah LR 545-637, 633 ("“"[i]nternationalists seem comfortable with power and uncomfortable with culture, while comparativists are eager for cultural understanding and wary of involvement with governance."). See also Kahn (Book), supra note 81 at 109-10 (suggesting there is something axiomatic in international law's approach to its field that makes it difficult if not almost impossible for them to employ the legal cultural approaches as described by Khan).

109 Vadi (fn 99) 104 (“ Like any other kind of adjudication, consistent patterns, attitudes, values and opinions characterize investment treaty arbitration. All these elements form what may be called a legal culture." - but the article goes no further.).

${ }^{110}$ See, e.g., $L i$ (fn 84) 487 (providing empirical data supporting the need for studies such as would be covered under legal cultural analyses).

${ }^{111}$ See generally, Mathias Reimann, 'Beyond National Systems: A Comparative Law for the International Age', (2001) 75 Tulane LR 1103-19. Also, as Demleitner notes: "comparative law focused on contrasting national legal systems rather than examining the non-dominant or informal sub-systems within the dominant legal structure or the developing international system." Nora V. Demleitner, 'Combating Legal Ethnocentrism: Comparative Law Sets Boundaries', (1999) 31 Arizona State LJ 737-762, 738.

${ }^{112}$ Reimann (Comparative Law) (fn 6) 680.

${ }^{113}$ See Momirov \& Fourie (fn 102).

${ }^{114}$ As Demleitner notes, "national and international legal systems, driven by economic globalization, migration and the advancement of human rights, have begun to mix, intersect and cross-fertilize. The resulting overlap of different normative orders in space and time leads to legal pluralism and intersectionality, the intersection of different legal orders which are "non-synchronic and thus result in uneven and unstable mixings of legal codes." Demleitner (fn 111) 746-47.
} 
out "sub silentio", without explicit methodological exposition. ${ }^{115}$ Though this may have been more the case in the previous generation of comparatists. Vivian Curran argues that the "elder statesmen" of American comparative law, as émigrés from Europe, "[b]eing of two countries, and sometimes more, the comparatist scholars of the last generation understood that translating from one legal discourse to another requires an understanding of the respective legal cultures." "116 Today's generation less typically has that innate understanding. Though, in some ways we cannot fault comparative (and international law scholars) for their failure to use legal cultural analyses, for legal academics in general have themselves been "relative latecomers to cultural analysis and cultural studies". 117

Despite the general failure to consider legal culture within the legal academy, comparatists should know better, for they are confronted with it more often and starkly than is likely the case for legal academics focused within domestic legal systems. Indeed, Nora Demleitner has noted that while "the original purpose of comparative law was to facilitate European cross-border trade through a comparison of legal rules, today it can assist in mediating conflicts that may arise from the cross border movement of persons who are imbued with the values of the legal culture into which they were born [and] can reveal how another person perceives the world, and how law contributes to and reflects the culture of a country." helping international legal regimes handle their interactions with domestic systems and peoples with different legal cultures. Demleitner further suggests the employment for human rights research of a methodology such as that proposed in this article, and says that if it were to be done then "comparative law could finally also live up to its promise and goal of becoming "a worldwide legal discipline". .

Having established that the methodology could and should be applied to research on international economic law, it remains to show how it could actually be implemented in practice. At a concrete level, that implementation or application of the methodology will be carried out by the three different groups of legal participants within international economic law-IEL scholars, practitioners, and officials. While there will be some overlap, generally speaking each of those groups will apply the methodology in different ways and in different contexts. As an initial matter, scholars are more likely to explicitly resort to the methodology, generally having the time and incentive to consider and present their methodological approaches. Not typically having pressing client or

\footnotetext{
${ }^{115}$ Curran (fn 35) 52.

116 ibid 53.

${ }^{117}$ See Sarat \& Simon (fn 55) 13 (quoting Robert Post: "We have long been accustomed to think of law as something apart. The grand ideals of justice, of impartiality and fairness, have seemed to remove law from the ordinary disordered paths of life. For this reason efforts to unearth connections between law and culture have appeared vaguely tinged with expose, as though the idol were revealed to have merely human feet. In recent years, with a firmer sense of the encompassing inevitability of cultue, the scandal has diminished, and the enterprise of actually tracing the uneasy relationship of law to culture has begin in earnest." From Robert Post (ed.), Law and the Order of Culture, at vii (University of California Press, Berkeley 1991)).

${ }^{118}$ Demleitner (fn 111) 745 (footnotes omitted).

119 ibid 758 (citing Mark Van Hoecke \& Mark Warrington, 'Legal Cultures, Legal Paradigms and Legal Doctrine: Towards a New Model for Comparative Law’, (1998) 47 ICLQ 495-536, 511).
} 
institutional demands on their research, scholars will more often than the other groups have the luxury of considering and apply different methodological approaches to the issues they are examining. Furthermore, due to the nature of the final product they produce, explicit presentation of their methodological approach is more likely than that in litigation or international organization legal documents. Furthermore, that application, divorced as it is from concrete or live disputes, can delve more deeply and into the more esoteric aspects of the legal cultural disconnects that may exist across and within the field. For example, the author is in the process of undertaking a scholarly analysis of the attitudes to the field of IEL scholars in communities with strong present and historic connections to Confucianism, such as those of China, Vietnam, Singapore, Hong Kong, Korea, and Taiwan. That project involves a carefully constructed and implemented survey of IEL scholars in those "Confucian" communities, attempting to tease out any different approaches to IEL that may be related to overt or subconscious legal cultural attitudes that may be related to Confucianism. ${ }^{120}$ For example, identification of a greater role for "virtue" in approaches and expected goals of IEL fields and institutions among those scholars might lend support to the idea that Confucianism is playing a role in their legal culture and in their understandings of and work within IEL. Of course, such studies are difficult and complex, and may often lead to inconclusive results. But, to the extent insights and useable results do emerge, they will be very important in the understanding and development of the field, particularly if for that project the study is extended to IEL officials from those societies.

While scholars have the luxury of being able to engage in detailed contemplations of the field, practitioners are forced to respond to the legal cultural issues that arise in the context of servicing clients in such areas as transnational disputes and transactions. Whenever there are dispute settlement proceedings and transactions involving participants from different legal cultures there is no question that identifying and understanding the legal cultural pressure points will be of great value. For example, in the international investment arbitration context, Jan Paulson recently discussed this very issue, noting the fact that "skilled advocates need to be attuned to the culture of the arbitrators they face is self-evident; it is an obvious and essential element of the internationally active advocate's credibility and persuasiveness." ${ }^{121}$ Paulson also noted the critical need to understand the legal culture of the advocates on the other side of a dispute, both with respect to their legal cultural behaviours within the arbitral hearings, but also outside those hearings. ${ }^{122}$ In significant part, practitioners learn, often through trial and error, how to navigate these legal cultural minefields through successive interactions with arbitrators and advocates from different legal cultural backgrounds. By knowing to look for legal cultural influences within the procedural and substantive law of the different fields and institutions within IEL, practitioners gain an advantage over those

\footnotetext{
${ }^{120}$ See, e.g., Picker (China) (fn 8) 77-82.

${ }^{121}$ J. Paulsson, 'Cultural Differences in Advocacy in International Arbitration', in Bishop/Kehoe (eds.), The Art of Advocacy in International Arbitration (2nd edition Juris Publishing) (2010) (available at Transnational Dispute Management (Nov. 2010) at 16.

${ }^{122}$ ibid 19. Understanding the legal cultural attitudes of diverse and foreign clients is also an important skill for a practitioner.
} 
that do not include such analysis in their work. For example, such advantage can be gained through the appropriate presentation of legal sources and authorities, such as the correct weight to be given to principles and treatises before arbitrators from a civilian legal culture. ${ }^{123}$ Similarly, understanding that counsel from common law jurisdictions may have an irrational attachment to their forms of civil procedure can be helpful when negotiating a compromis. ${ }^{124}$ While not usually dispositive, the small gains may be sufficient to tilt the balance in favour of the party employing the legal cultural analysis, just as those skilled in private international law have an advantage over opposition less skilled in choice of law analysis.

Governmental and international organization officials will also find legal cultural analyses helpful, both within proceedings, similarly to practitioners, and also as they seek to develop the law, similarly to scholars. Additionally, due to the cosmopolitan nature of international organizations, both international organization officials and the member states delegation officials of those organizations must navigate a complex mix of legal cultures - within the organization among the different individuals that work there as well as within the resultant substantive and procedural law of the organization. Thus, an American government official working at the WTO in Geneva, will often work with officials from the other delegations as well as with the WTO's officials, who are themselves very likely to reflect the legal cultures of their home jurisdictions. ${ }^{125}$ Furthermore, all those officials must learn to work with a substantive and procedural law that is likely to reflect the numerous legal cultural heritages of those involved in the creation and development of the organization. Of course, like practitioners, through experience official should be able to learn to look out for the legal cultural conflicts that must inevitably arise within such organizations. But, there is a risk that the legal cultural issues will be subconsciously ignored, under the misapprehension that legal culture is an issue for domestic law alone, and not present within the international legal order. ${ }^{126}$ Greater explicit consideration of legal culture and comparative legal cultural analyses will help to counter that fallacy. Finally, for international organizations there are also important internal institutional applications of the methodology that are less present for scholars and practitioners. ${ }^{127}$ Employment of legal cultural analysis will help to reveal legal cultural influences within the international organization, influences that may not always be in the best or long term interest of the organization or field. For example, a strong common law legal cultural influence may undermine the acceptability of the organization and its law with non-common law systems, the majority in the world, and may impede implementation within those non-common law systems. ${ }^{128}$

\footnotetext{
${ }^{123}$ See Mary Ann Glendon, Paolo G. Carozza \& Colin B. Picker, Comparative Legal Traditions: Texts, Materials And Cases On Western Law (3rd Edition West 2007) at 241-248.

${ }^{124}$ See, e.g., Stephen Goldstein, 'The Odd Couple: Common Law Procedure and Civilian Substantive Law', (2003) 78 Tulane LR 291-306, 293 (discussing "the emotional, almost religious attachment of the adherents of the common law procedure to their system.").

${ }^{125}$ See generally, Picker (IOs) (fn 37).

${ }^{126}$ See above note 102.

${ }^{127}$ Though, given the increasing internationalization of many law firms and law schools, consideration of legal culture within the firm or law school would also likely be beneficial.

${ }^{128}$ See generally, Picker (IO) (fn 37).
} 
Even after each of the above different IEL participants commits to employing legal cultural analyses, they are then faced with the difficulties associated with the application of this methodology that spans the two typically separate fields of international and comparative law. Furthermore, because comparative legal cultural analyses focus on behaviour and sociological indicators, IEL legal actor participants will need to learn to think differently. While still important, the traditional doctrinal approaches to sources of law, processes and institutions may need to be supplemented with the more nuanced and often behaviourist approach that will often be associated with comparative legal cultural analyses. In addition, because different legal cultures will be at issue, comparative law considerations may be more central. Those comparative considerations might include traditional comparative methodological approaches to employment of the substantive content of comparative law-its attention to the legal classifications and the differing legal approaches within the many different major and sometimes minor traditions and systems. It may be that trained and expert comparatists will need to be involved, both for their knowledge and their approaches. If nothing else, it should become clear to IEL legal participants that excessive specialization that does not include comparative law may not be the best approach for operating in an increasingly interconnected field.

\section{CONLUSION}

While the proposal in this article is not nearly so grand or momentous, an apt analogy that helps to convey the contribution of the article to the field would be when the telescope which had only been used to see distant objects at sea or on land was improved by Galileo, permitting him to turn it on the night sky for the first time. That new use revealed that the Milky Way was composed of stars, that the surface of the moon had craters and mountains, and that Jupiter had moons. ${ }^{129}$ While that early telescope did not provide many answers, it raised new and important questions and provided insights into our understandings of the Earth, the night sky and the universe. Similarly, while many answers are not provided by this article, novel insights are illuminated that will lead to new questions and lines of inquiry, and eventually, through later similar studies, will lead to greater understandings of the international legal order.

${ }^{129}$ Encyclopedia Britanica (15 ${ }^{\text {th }}$ edition), vol. 7 (1990), at 640. 